https://doi.org/10.15407/scine17.01.096

PONOMARENKO, O.M., SAMCHUK, A.I., VOVK, K.V., ZAIATS, O.V., and KURAEVA, I.V.

Semenenko Institute of Geochemistry, Mineralogy and Ore Formation the NAS of Ukraine, 34, Akad. Palladina Ave., Kyiv, 03142, Ukraine, +380 44424 1270, office.igmr@gmail.com

\title{
THE NEWEST ANALYTICAL TECHNOLOGIES FOR DETERMINING RARE-EARTH ELEMENTS IN GRANITOIDS OF THE UKRAINIAN SHIELD
}

Introduction. To date, rare earth elements (REE) are used to manufacture most high-tech goods and are crucial in defense technologies (lasers, radars, and electromagnetic weapons), nuclear engineering, metallurgy, and others. All this determines the relevance of their study to assess the rare earth mineral resource base of Ukraine.

Problem Statement. The determination of REE in rocks and minerals is a fundamental problem in geochemistry and petrology for understanding the processes of rock formation. However, it is a complex analytical task related to the similar chemical properties of these elements, which are caused by the "lanthanide compression effect".

Purpose. The purpose is to develop analytical technologies for determining REE content by the ICP-MS method, to evaluate their content and distribution in granitoids of the Ukrainian Shield.

Materials and Methods. The hybrid method of ICP-MS analysis and microwave decomposition of rocks and minerals has been used to measure the REE content. This technique has been tested and used to estimate the content and distribution of REE in fluorites and rare-metal granitoids of the Ruska Polyana massif of the KorsunNovomyrhorod pluton of the Ukrainian Shield.

Results. Analytical technologies for determination of REE in granites and minerals have been developed. The method for determining REE in fluorites and granites without their prior concentration in the range from 0.01 to 1000 ppm with a relative standard deviation of 0.01-0.10 has been described. The content of rare earth elements in the Ruska Polyana granites increases $(218-797 \mathrm{~g} / \mathrm{t}$ ), the main concentrator of these elements is fluorite $(692-26933 \mathrm{~g} / \mathrm{t}$ REE). An inverse relationship has been observed between the REE content in fluorites and granites.

Conclusions. The developed analytical technologies are the basis for establishing quality assessment criteria and developing principles for the rational use of rare-earth granitoids to create a rare-earth mineral resource base in Ukraine.

Keywords: rare earth elements, ICP-MS-analysis, granitoids, and fluorite.

Citation: Ponomarenko, O.M., Samchuk, A.I., Vovk, K.V., Zaiats, O.V., and Kuraeva, I.V. The Newest Analytical Technologies for Determining Rare-Earth Elements in Granitoids of the Ukrainian Shield. Sci. innov. 2021. V. 17, no. 1. P. 96-102. https://doi.org/10.15407/scine17.01.096 
Determination of rare earth elements (REE) content in rocks and minerals is of fundamental importance for various fields of science and technology, especially in geochemistry and petrology for understanding the rock formation processes [1, $2]$. At the same time, this is the most complicated analytical task because of similar chemical properties of REE caused by the "lanthanide compression effect".

The use of such techniques as X-ray fluorescence (XRF), neutron activation (NA), atomic emission spectrometry (AES) in the REE analysis has significant limitations because of the lack of sensitivity, inability to determine all rare earth elements, and matrix effects in natural objects [1,3].

Today, inductively coupled plasma mass spectrometry (ICP-MS analysis) is the most effective method in the analysis of rocks and minerals to determine the content of REE. Nowadays, analysts are increasingly getting interested in developing new effective methods for preparing geological objects with the use of microwave systems. This interest in microwave radiation for sample preparation is explained by the acceleration of physicochemical processes during the decomposition of samples in acids and the achievement of complete decomposition [4,5].

For ICP-MS analysis, the efficient sample preparation schemes shall provide the following conditions: first, complete extraction of the rare earth elements to be determined from the test sample; second, the ability to determine many components from a single solution; third, a low signal of the blank sample, which is especially important in determining a nanogram content of the elements; the minimization of mineral barriers and the matrix block effect; the separation of some aggressive and toxic components that interfere with the separation of spectra (eg, fluoride ions, organic solvents); the use of reference samples of minerals and rocks; a high sensitivity and reproducibility of the measurements.

The development of hybrid methods of ICPMS-analysis and microwave systems for the decomposition of rocks may significantly improve the analytical characteristics of the determination of REE content in mineral raw materials and raise the efficiency of its use.

The purpose of this research is to develop cutting-edge analytical technologies for measuring the content of REE by ICP-MS technique, with the use of a microwave field, as well as for determining their content and distribution in the granitoids of the Ukrainian Shield.

Concentrated acids $\mathrm{HF}, \mathrm{HCl}, \mathrm{HNO}_{3}$, and $\mathrm{H}_{2} \mathrm{SO}_{4}(\mathrm{ppm})$, which are additionally purified with the use of the SUBBOILING system have been used. Water with a resistance of $18.2 \mathrm{Mohm}$ is obtained with the use of the DIRECT-03 system from MILLIPORE (USA). The samples are dissolved in a microwave oven ETNOS by MILISTONE (Italy). The operating frequency of microwave radiation is $2,450 \mathrm{MHz}$; the maximum power is $1,600 \mathrm{~W}$. The temperature and decomposition time of natural objects are set by a sensor with ceramic and Teflon coating, by means of which the parameters during the reactions in the autoclaves are controlled, with the use of a terminal with a color monitor.

The content of rare earth elements is determined by an induction-coupled plasma mass spectrometer (ICP-MS) of the ELEMENT-2 analyzer (Germany). Indium (115In) is used as an internal reference; granite CO-3739 (Canada) and basalt JB-3 (Japan) are used as an external reference [3].

The samples for ICP-MS analysis are prepared according to the following analytical schemes [4-8]:

1. Decomposition of hydrofluoric and nitric acids in a microwave oven. A portion of $0.1 \mathrm{~g}$ test material is placed in a Teflon autoclave; $10 \mathrm{ml}$ hydrofluoric acid and $10 \mathrm{ml}$ nitric acid (density $1.4 \mathrm{~g} / \mathrm{cm}^{3}$ ) are added. The rotor is placed into the microwave oven that is heated at $230{ }^{\circ} \mathrm{C}$ for $35 \mathrm{~min}$, according to the program. If the sample decomposition is incomplete, the treatment is repeated. After cooling the autoclave to remove fluorine, the solution is evaporated in a sand bath until the salts dry out. The residual salts are dissolved by hea- 
ting with $10 \%$ nitric acid. The solution is transferred to a $50 \mathrm{ml}$ volumetric flask, with the volume adjusted up to the mark with a $5 \%$ solution of the same acid.

2. Decomposition of minerals in a mix of sulfuric, hydrofluoric, and nitric acids in a microwave oven. $0.1 \mathrm{~g}$ samples are placed into the autoclaves, adding $10 \mathrm{ml}$ hydrofluoric acid, $3 \mathrm{ml}$ sulfuric acid, and $2 \mathrm{ml}$ nitric acid. The rotor with autoclaves is placed in the microwave oven that is heated at $240{ }^{\circ} \mathrm{C}$ for 30 minutes, according to the program. If the sample decomposition is incomplete, the treatment is repeated. After cooling the autoclaves, the solution is evaporated in a sand bath until thick white vapors of sulfuric acid appear. The residual salts are dissolved by heating in 5\% nitric acid. The solution is poured into a $50 \mathrm{ml}$ volumetric flask, with the volume adjusted to the mark with 5\% nitric acid solution.

3. Combined method of decomposition based on dissolution in nitric and sulfuric acids and further fusion of the insoluble residue with lithium metaborate. A portion of $0.1 \mathrm{~g}$ test material is placed into the autoclave, adding $10 \mathrm{ml}$ hydrofluoric acid, $2 \mathrm{ml}$ sulfuric acid, and $5 \mathrm{ml}$ nitric acids, and decomposed in the microwave oven at $240^{\circ} \mathrm{C}$ for 30 minutes, according to the program. After cooling the autoclave, the solution is evaporated up to release of sulfur anhydride. After cooling, the walls of the cup are washed with water, with evaporation repeated until complete dryout. The dry residue is dissolved in $10 \mathrm{ml} \mathrm{15 \%} \mathrm{nitric} \mathrm{acid;} \mathrm{the}$ insoluble precipitate is filtered through a fine filter, washed with $3 \%$ nitric acid solution and further with water. The filter with the precipitate is placed in a platinum crucible, dried and ashed. The residue is fused with $0.4 \mathrm{~g}$ lithium metaborate at $1,000{ }^{\circ} \mathrm{C}$ for $20 \mathrm{~min}$. The fusion is dissolved in $10 \%$ nitric acid solution; the resulting solution is added to the stock that is poured into a $50 \mathrm{ml}$ volumetric flask, with the volume adjusted to the mark with $5 \%$ nitric acid solution.

It has been established that the first analytical scheme does not provide a complete decomposition of rocks and requires additional treatment in more severe conditions. The use of the third analytical scheme (combined decomposition method) has proved to be the most effective in dissolving the most stable silicate rocks. However, this scheme has significant drawbacks. It is more energy intensive and requires the introduction of an additional process of fusion with sodium metaborate.

The second scheme of decomposition of granites and fluorites (decomposition in a mix of sulfuric, hydrofluoric. and nitric acids) has proved to be the most effective in comparison with the other analytical schemes. Table 1 shows the results of the determination of REE content with the use of the microwave decomposition method of in reference samples having various composition: basalt JB-3 (Japan) and granite CO3739 (Canada).

The obtained results of REE content measurement correspond to the accepted certified values. The error of determination does not exceed $10 \%$, and the relative standard deviation is $0.08-0.1$. Hence, the application of the tested method al-

Table 1. The Results fo ICP-MS Measurements of REE Content (ppm) in Reference Samples of Basalt JB-3 (Japan) and Granite CO-3739 (Canada)

\begin{tabular}{|c|c|c|c|c|}
\hline \multirow{2}{*}{$\begin{array}{c}\text { Ele- } \\
\text { ment }\end{array}$} & \multicolumn{4}{|c|}{ Sample } \\
\cline { 2 - 5 } & \multicolumn{2}{|c|}{ JB-3 } & \multicolumn{2}{c|}{ CO-3739 } \\
\cline { 2 - 5 } & $\begin{array}{c}\text { Certified, } \\
\mathrm{c} \pm \Delta, \mathrm{ppm}\end{array}$ & $\begin{array}{c}\text { Detected, } \\
\mathrm{c} \pm \Delta, \mathrm{ppm}\end{array}$ & $\begin{array}{c}\text { Certified, } \\
\mathrm{c} \pm \Delta, \mathrm{ppm}\end{array}$ & $\begin{array}{c}\text { Detected, } \\
\mathrm{c} \pm \Delta, \mathrm{ppm}\end{array}$ \\
\hline $\mathrm{La}$ & $8.8 \pm 0.8$ & $8.5 \pm 0.6$ & $38.9 \pm 2.1$ & $38.1 \pm 2.2$ \\
$\mathrm{Ce}$ & $22 \pm 2$ & $24 \pm 3$ & $103.3 \pm 8.1$ & $101.1 \pm 3.1$ \\
$\mathrm{Pr}$ & $3.4 \pm 0.4$ & $3.0 \pm 0.5$ & $12.65 \pm 0.1$ & $12.1 \pm 0.4$ \\
$\mathrm{Nd}$ & $16 \pm 2$ & $17 \pm 1$ & $48.9 \pm 1.9$ & $47.1 \pm 1.6$ \\
$\mathrm{Sm}$ & $4.3 \pm 0.3$ & $5.1 \pm 0.8$ & $6.3 \pm 0.2$ & $6.1 \pm 0.4$ \\
$\mathrm{Eu}$ & $1.3 \pm 0.1$ & $1.1 \pm 0.2$ & $1.69 \pm 0.16$ & $1.68 \pm 0.2$ \\
$\mathrm{Cd}$ & $4.7 \pm 0.6$ & $4.1 \pm 0.7$ & $3.35 \pm 0.3$ & $3.39 \pm 0.3$ \\
$\mathrm{~Tb}$ & $0.73 \pm 0.09$ & $0.8 \pm 12$ & $0.44 \pm 0.3$ & $0.40 \pm 0.08$ \\
$\mathrm{Dy}$ & $4.5 \pm 0.4$ & $4.7 \pm 0.03$ & $1.77 \pm 0.12$ & $1.70 \pm 0.14$ \\
$\mathrm{Ho}$ & $0.8 \pm 0.2$ & $0.95 \pm 0.15$ & $0.25 \pm 0.14$ & $0.24 \pm 0.12$ \\
$\mathrm{Er}$ & $2.5 \pm 0.4$ & $2.8 \pm 0.6$ & $0.8 \pm 0.2$ & $0.8 \pm 0.1$ \\
$\mathrm{Tm}$ & $0.42 \pm 0.05$ & $0.40 \pm 0.04$ & $0.12 \pm 0.09$ & $0.11 \pm 0.01$ \\
$\mathrm{Yb}$ & $2.6 \pm 0.5$ & $2.4 \pm 0.2$ & $0.68 \pm 0.08$ & $0.67 \pm 0.1$ \\
$\mathrm{Lu}$ & $0.39 \pm 0.06$ & $0.35 \pm 0.04$ & $0.09 \pm 0.01$ & $0.09 \pm 0.01$ \\
\hline
\end{tabular}

Note: $c$ is element concentration, $\Delta$ is standard deviation. 
lows determining the content and distribution of REE in granitoids and minerals.

With the use of the developed method, the content of rare earth elements in fluorites and granites containing REE of the Ruska Polyana massif of the Korsun-Novomyrhorod pluton of the Ukrainian shield has been studied. The geological, mineralogical, and geochemical features of these granites have been described in detail in $[9-10]$.

The content of rare earth elements in the Ruska Polyana granites increases. The amount of REE ranges within 218-797 g/t (Table 2). The content of heavy REE gradually grows from mediumgrained and porphyritic granites to fine-grained ones, while that of light REE decreases, with the europium minimum going deeper.

Among the studied fluorites and their granites (Table 2), the highest content of lanthanides
$(26933 \mathrm{~g} / \mathrm{t})$ and yttrium (11705 g/t) has been found in fluorites from fine- and medium-grained gray-pink granites of the upper part of the well, with the fine-grained gray-pink ones having the lowest total content of lanthanides $(218 \mathrm{~g} / \mathrm{t})$ and the highest content of yttrium. The lowest contents of lanthanides $(692 \mathrm{~g} / \mathrm{t})$ and yttrium $(831 \mathrm{~g} / \mathrm{t})$ have been determined in the fluorites from medium-grained gray-pink granites of the deepest part of the well. The medium-grained gray-pink granites are characterized by a high content of lanthanides $(797 \mathrm{~g} / \mathrm{t})$.

There has been recorded an inverse relationship between the content of $\Sigma$ REE in fluorites and their granites (Fig. 1). In the fluorites from fine- and medium-grained gray-pink granites of the upper part of the well section, the content of $\Sigma$ REE is approximately 120 times higher than the content of $\Sigma$ REE in the granites (Fig. 1, $a$ ).

Table 2. The Content of REE in Ruska Polyana Granites and Fluorites at Four Depths of Well No. 8568, g/t

\begin{tabular}{|l|c|c|c|c|c|c|c|c|}
\hline \multirow{2}{*}{ Component } & \multicolumn{7}{|c|}{ Granites } & \multicolumn{4}{c|}{ Fluorites } \\
\cline { 2 - 9 } & \multicolumn{7}{|c|}{ Depth, m } \\
\cline { 2 - 9 } & $156.1-158.0$ & $174.6-176.5$ & $225.0-227.0$ & $239.6-242.0$ & $156.1-158.0$ & $174.6-176.5$ & $225.0-227.0$ & $239.6-242.0$ \\
\hline La & 26 & 182 & 100 & 202 & 4631 & 1045 & 2776 & 119 \\
$\mathrm{Ce}$ & 58 & 221 & 148 & 264 & 9384 & 1882 & 5059 & 223 \\
$\mathrm{Pr}$ & 8 & 31 & 22 & 42 & 1202 & 222 & 537 & 26 \\
$\mathrm{Nd}$ & 32 & 101 & 81 & 149 & 4675 & 1058 & 2054 & 109 \\
$\mathrm{Sm}$ & 11 & 20 & 18 & 32 & 1203 & 376 & 385 & 29 \\
$\mathrm{Eu}$ & 0.30 & 0.58 & 0.77 & 1.26 & 10.3 & 1.8 & 6.4 & 0.8 \\
$\mathrm{Gd}$ & 14 & 19 & 17 & 32 & 1162 & 575 & 340 & 39 \\
$\mathrm{~Tb}$ & 3 & 4 & 3 & 5 & 207 & 116 & 53 & 7 \\
$\mathrm{Dy}$ & 21 & 22 & 17 & 29 & 1613 & 807 & 293 & 51 \\
$\mathrm{Ho}$ & 5 & 5 & 4 & 6 & 349 & 194 & 58 & 12 \\
$\mathrm{Er}$ & 16 & 15 & 10 & 16 & 1062 & 589 & 155 & 35 \\
$\mathrm{Tm}$ & 3 & 2 & 2 & 2 & 168 & 90 & 22 & 5 \\
$\mathrm{Yb}$ & 18 & 14 & 10 & 13 & 1102 & 580 & 133 & 31 \\
$\mathrm{Lu}$ & 3 & 2 & 2 & 2 & 165 & 89 & 20 & 5 \\
$\Sigma \mathrm{P} 3 \mathrm{E}$ & 218 & 639 & 435 & 797 & 26933 & 7625 & 11891 & 692 \\
$\Sigma \mathrm{Ce}$ & 149 & 575 & 387 & 724 & 22267 & 5160 & 11157 & 546 \\
$\Sigma \mathrm{Y}$ & 69 & 64 & 48 & 73 & 4666 & 2465 & 734 & 146 \\
$\mathrm{Eu} / \mathrm{Eu}$ & 0.072 & 0.090 & 0.134 & 0.121 & 0.027 & 0.012 & 0.054 & 0.070 \\
$(\mathrm{La} / \mathrm{Yb})_{\mathrm{N}}$ & 1.00 & 8.55 & 7.02 & 10.43 & 2.84 & 1.22 & 14.11 & 2.61 \\
\hline
\end{tabular}



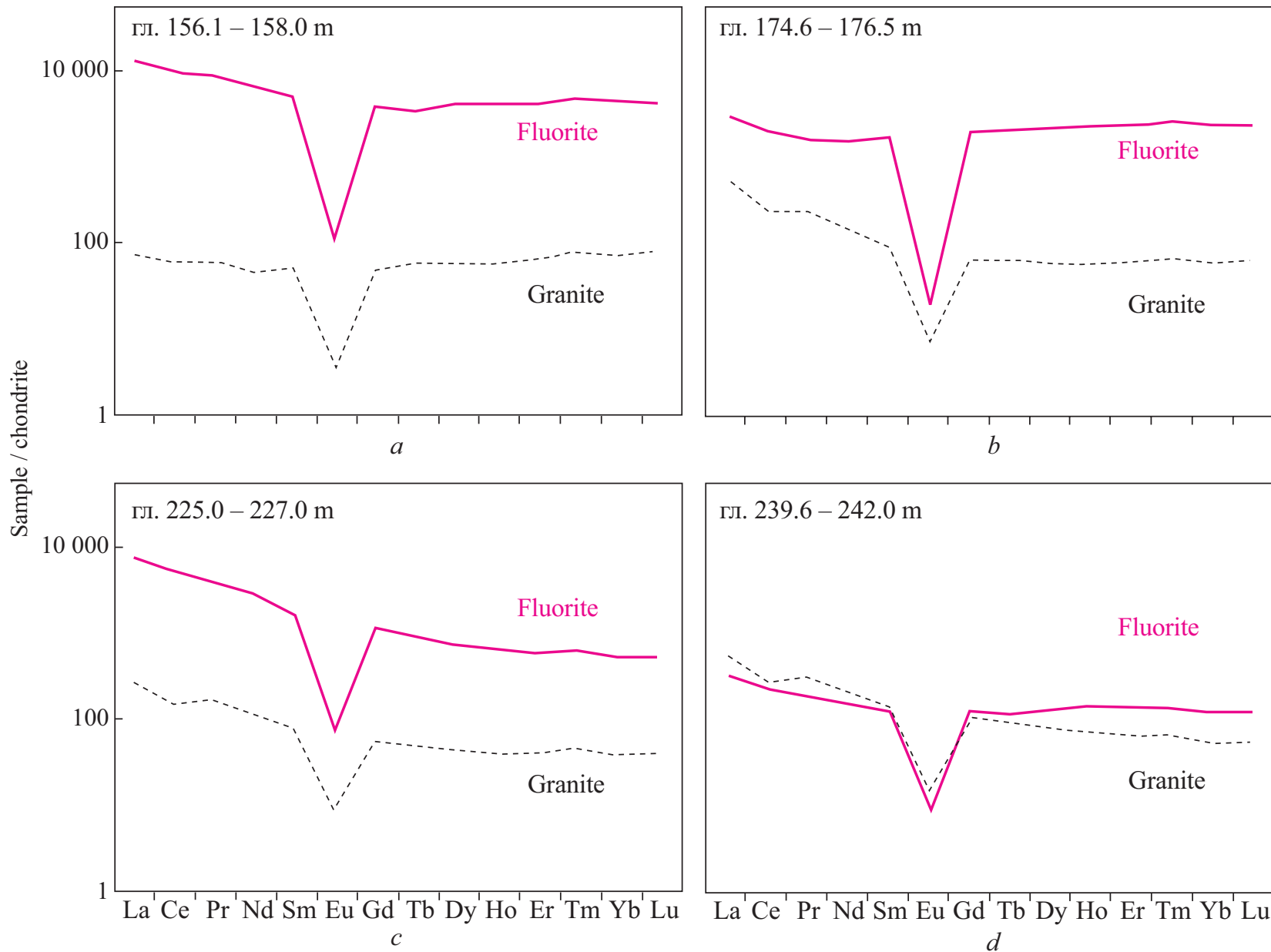

гл. $239.6-242.0 \mathrm{~m}$

Fig. 1. Spectra of REE distribution in the fluorites (solid red line) and in the Ruska Polyana granites containing them (dash black line) from the four depths of well No. 8568

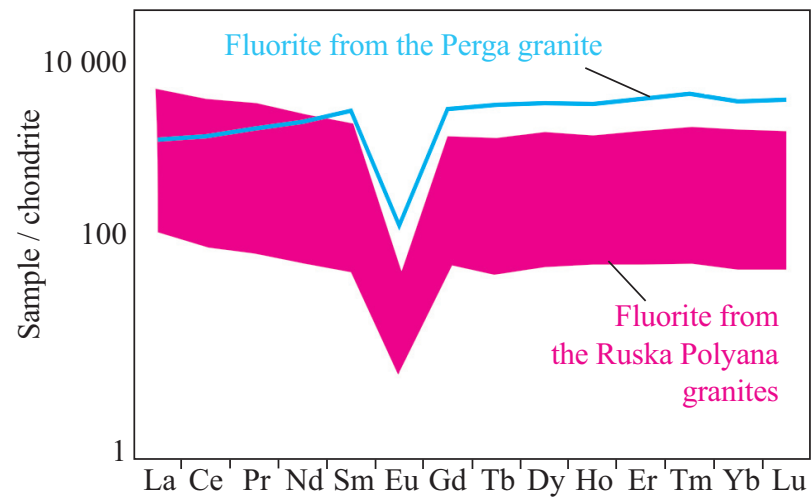

Fig. 2. REE distribution inn the fluorite of the Perga granite ([11]) and in the studied fluorites of the Ruska Polyana granites from the four depths of well No. 8568
Going deeper, this gap decreases significantly (Fig. 1, $a-d$ ) and in the medium-grained graypink granites of the deepest part of the well, the content of $\sum$ REE is higher than in the fluorites (Fig. 1, $d$ ).

It should be noted that in terms of the total content of lanthanides, the fluorites from fine-grained gray-pink Ruska Polyana granites $\left(\sum \mathrm{REE}=\right.$ $=26933 \mathrm{~g} / \mathrm{t}$ ) is comparable to the fluorites from the Perzhanskyi granite $\left(\sum \mathrm{REE}=23390 \mathrm{~g} / \mathrm{t}\right)[11]$. The Perga fluorite differs from the Ruska Polyana fluorites (Fig. 2) by a different ratio of cerium and yttrium subgroups of lanthanides with $\Sigma \mathrm{Ce}$ / $\Sigma \mathrm{Y}=1.33$. 
Thus, the state-of-the-art analytical technologies for preparing rock samples for ICP-MS analysis with the use of a microwave field have been developed. The method for determining REE in fluorites without prior concentration in the range from 0.001 to $1000 \mathrm{ppm}$ with a relative standard deviation of $0.01-0.10$ has been presented.

The content and distribution of rare earth elements in fluorites and granites containing rare earth metals of the Ruska Polyana massif have been determined. These granites are characterized by a high content of REE $(218-797 \mathrm{~g} / \mathrm{t})$. The main concentrator of REE is fluorite (up to $26933 \mathrm{~g} / \mathrm{t}$ ).

The proposed analytical technologies are the basis for establishing quality assessment criteria and for developing principles of the rational use of rare-earth granitoids to create a rare-earth mineral resource base in Ukraine.

\section{REFERENCES}

1. Thomson, M. A. (1998). Guide to spectrometric analysis with inductively coupled plasma. Moscow: Nedra [in Russian].

2. Samchuk, A. I., Pilipenko, A. T. (1987). Analytical chemistry of minerals. Utrecht, The Netherlands: VNU Science Press.

3. Ponomarenko, O., Samchuk, A., Ogar, T., Petrichenko, K., Popenko, E., Krasyuk O. (2012). Determination of Rare Earth Elements in Rocks and Minerals by Inductively Coupled Plasma Mass Spectrometry (ICP-MS). Geologist of Ukraine, 3(39), 36-40 [in Ukrainian].

4. Ponomarenko, O. M., Samchuk, A. I., Krasiuk, O. P., Makarenko, T. I., Antonenko, O. G. (2008). Analytical Schemes for the Preparation of Rocks and Minerals and their Determination of Trace Elements by Inductively Coupled Plasma Mass Spectrometry (ICP-MS). Mineralogical Journal, 4, 97-103 [in Ukrainian].

5. Samchuk, A. I., Ponomarenko, O. M., Antonenko, O. G. (2010). Analytical schemes of microwave decomposition of rocks and minerals and determination of microelements in them by inductively coupled plasma mass spectrometry. Ukrainian Chemical Journal, 10, 115-121 [in Ukrainian].

6. Patent of Ukraine № 131775. Ponomarenko O.M., Samchuk A.I., Zayat O.V., Vovk K.V. The method of rare earth elements determining [in Ukrainian].

7. Samchuk, A. I., Pilipenko, A. T. (1982). Analytical chemistry of minerals. Kyiv: Naukova dumka [in Russian].

8. Ponomarenko, O. M., Samchuk, A. I.,. Wozniak, D. K., Vovk, K. V., Belskyi, V. M. (2018). Features of the rare-earth elements determination by mass spectrometry in fluorites and rocks of the Suschany-Perga ore zone. Ukrainian Chemical Journal, 4(84), 118-122 [in Ukrainian].

9. Zayets, O. V. (2017). Geochemistry of Ruska-Polyana rare-metal granitoids of the Korsun-Novomyrgorod pluton. Extended abstract of candidate's thesis. Kyiv [in Ukrainian].

10. Zayets, O. V. (2015). Geochemistry of Ruska-Polyana rare-metal granitoids of the Korsun-Novomyrgorod pluton. Mineralogical Journal, 3, 67-77 [in Ukrainian].

11. Ponomarenko, O. M., Voznyak, D. K., Samchuk, A. I., Belskyi, V. D. (2017). To the origin of the fluorite of the SushanyPerga ore zone. Reports of NAS of Ukraine, 11, 52-58 [in Ukrainian].

Received 15.01.20

Revised 28.01.20

Accepted 17.02.20

О.М. Пономаренко, А.І. Самчук,

К.В. Вовк, О.В. Заящ, І.В. Кураєва

Інститут геохімії, мінералогії та рудоутворення ім. М.П. Семененка НАН України,

просп. Акад. Палладіна, 34, Київ, 03142, Україна,

+380 44424 1270, office.igmr@gmail.com

НОВІТНІ АНАЛІТИЧНІ ТЕХНОЛОГІї

ДЛЯ ВИЗНАЧЕННЯ РІДКІСНОЗЕМЕЛЬНИХ ЕЛЕМЕНТІВ

У ГРАНІТОЇДАХ УКРАЇНСЬКОГО ЩИТА

Вступ. На сьогодні рідкісноземельні елементи (РЗЕ) використовуються для виготовлення більшості високотехнологічних товарів і мають ключове значення в оборонних технологіях (лазери, радари та електромагнітна зброя), атом- 
ній техніці, металургії та ін. Все це обумовлює актуальність їхнього дослідження для надання оцінки рідкісноземельної мінерально-сировинної бази України.

Проблематика. Визначення РЗЕ в гірських породах та мінералах має фундаментальне значення в геохімії та петрології для пізнання процесів породоутворення. Але, разом з тим, визначення останніх є складним аналітичним завданням, пов’язаним з близькими хімічними властивостями цих елементів, які обумовлені «ефектом лантаноїдного стиснення».

Мета. Розробка новітніх аналітичних технологій визначення вмісту РЗЕ методом мас-спектрометрії з індукційно зв'язаною плазмою, а також оцінка їх вмісту та розподілу в гранітоїдах Українського щита.

Матеріали й методи. Використано гібридну методику ICP-MS-аналізу та мікрохвильового розкладу гранітів та мінералів для визначення вмісту РЗЕ. Методику протестовано та використано для оцінки вмісту та розподілу РЗЕ у флюоритах та вміщуючихїх рідкіснометалевих гранітоїдів Русько-Полянського масиву Корсунь-Новомиргородського плутону Українського щита.

Результати. Розроблено новітні аналітичні технології визначення РЗЕ в гранітах та мінералах. Викладено методику визначення РЗЕ у флюоритах та гранітах без попереднього концентрування в діапазоні від 0,001 до 1000 ppm 3 відносним стандартним відхиленням 0,01-0,10. Показано підвищений вміст рідкісноземельних елементів у руськополянських гранітах (218-797 г/т), головним концентратором яких є флюорит (692-26933 г/т РЗЕ). Між вмістом РЗЕ у флюоритах та гранітах спостерігається обернена залежність.

Висновки. Розроблені аналітичні технології є базисом для встановлення критеріїв оцінки якості та розробки принципів раціонального використання рідкісноземельних гранітоїдів для створення рідкісноземельної мінеральносировинної бази на Україні.

Ключові слова: рідкісноземельні елементи, ICP-MS-аналіз, гранітоїди, флюорит. 